\title{
The Influence of Dimension Effect on the Hydrothermal Aging Behavior of Aramid/Epoxy Composites
}

\author{
Zeynal Abidin OĞUZ ${ }^{* 1}$, Ahmet ERKLİĞ ${ }^{2}$ \\ ${ }^{1}$ General Directorate of State Hydraulic Works, Adlyaman \\ ${ }^{2}$ Gaziantep University, Faculty of Engineering, Mechanical Engineering Department, \\ Gaziantep
}

Geliş tarihi: 02.03.2021 Kabul tarihi: 31.03 .2021

\begin{abstract}
An investigation was carried out concerning the hydrothermal aging effect on the water intake character of aramid/epoxy composites based on the dimension effect. The aramid/epoxy composites were manufactured by the vacuum assisted resin infusion method (VARIM) kept in distilled water and sea water at $25{ }^{\circ} \mathrm{C}$ and $70{ }^{\circ} \mathrm{C}$ for 6 weeks in a controllable aging cabin. The water absorption behavior of composite samples cut with different length/width $(\mathrm{L} / \mathrm{w})$ ratios was assessed according to different water types and temperatures. Besides, the water intake character of aramid/epoxy samples was interpreted theoretically according to the Fick model. The experimental and theoretical results showed that aramid/epoxy composites displayed a tendency consistent with the Fickian model. Further, the water intake character of aramid/epoxy samples was affected by criteria such as sea water, distilled water, temperature, and different $\mathrm{L} / \mathrm{w}$ ratio. The temperature increase was caused to more water absorption. Further, the increase of $\mathrm{L} / \mathrm{w}$ ratio was caused to more water intake for both water types.
\end{abstract}

Key Words: Aramid/epoxy, Hydrothermal aging, Distilled water, Sea water

\section{Numune Boyut Etkisinin Aramid/Epoksi Kompozitlerin Hidrotermal Yaşlanma Davranıșına Etkisi}

Öz

Boyut etkisine bağlı olarak aramid/epoksi kompozitlerin su emme davranışı üzerindeki hidrotermal yaşlanma etkisi ile ilgili bir araştırma yapılmıştır. Vakum destekli reçine transfer yöntemi (VARIM) ile üretilen aramid/epoksi kompozitler, kontrol edilebilir bir yaşlandırma kabininde 6 hafta boyunca saf su ve deniz suyuna $25{ }^{\circ} \mathrm{C}$ ve $70{ }^{\circ} \mathrm{C}$ sıcaklıklarda daldırılmıştır. Farklı uzunluk/genişlik (L/w) oranlarında kesilen kompozit numunelerin su emme davranışları, farklı su tipleri ve sıcaklıklara göre değerlendirilmiştir. Ayrıca aramid/epoksi numunelerinin su emme özelliği teorik olarak Fick modeline göre yorumlanmıştır. Deneysel ve teorik sonuçlar, aramid/epoksi kompozitlerinin Fickian modeliyle tutarlı bir eğilim sergilediğini göstermiştir. Ayrıca aramid/epoksi kompozit numunelerin su emme

"Sorumlu Yazar (Corresponding author): Zeynal Abidin OĞUZ, oguzeynal02@gmail.com 
davranışı, deniz suyu, saf su, sıcaklık ve farklı L/w oranı gibi kriterlerden etkilenmiştir. Sıcaklık artı̧̧ı daha fazla su emilimine neden olmuştur. Ayrıca, L/w oranındaki artış, her iki su türü için daha fazla su alımına neden olmuştur.

Anahtar Kelimeler: Aramid/epoksi, Hidrotermal yaşlanma, Saf su, Deniz suyu

\section{INTRODUCTION}

Polymer-based matrix composites are used in a wide range of applications from advanced engineering to daily usage due to their superior properties such as lightweight, high specific strength, good fatigue properties, excellent vibration damping [1,2]. Although its mechanical properties are superior to other material classes, the moisture and water absorption of polymer composites is caused to deteriorate their mechanical properties. In most of the studies in the literature conducted to see how the mechanical properties of composite materials are affected by different environmental conditions, water absorption tendencies were also examined. In the studies, the effects of criteria such as humidity level, water type, temperature, and aging time on the water absorption of composite samples were investigated. However, an investigation based on sample sizes has not been clarified. In this section, information will be given about similar studies that can be associated with this study.

The analysis of the aramid/epoxy interfacial behaviors was examined by Tanaka et al. [3] using pull-out tests and the effect of water uptake. In this study, aramid/epoxy specimens were aged in distilled water at $80^{\circ} \mathrm{C}$ for $4,7,10$, and 13 weeks. A rapid weight gain was seen in the first 4 weeks. Water absorption continued to increase until the $10^{\text {th }}$ week. However, there was no change in the weight of the samples between the $10^{\text {th }}$ week and the $13^{\text {th }}$ week. The water gain ratios of aramid/epoxy composites were found as $1.9 \%$, $2.0 \%, 2.1 \%$, and $2.1 \%$ after $4,7,10$, and 13 weeks aging period, respectively.

Akay et al. [4] tried to see the moisture intake behavior of Kevlar-49/epoxy resin by using Fiberite and Brochier systems and its effect on the thermal and mechanical behavior. Samples were kept for three weeks at $70{ }^{\circ} \mathrm{C}$ with $95 \%$ and $100 \%$ relative humidity, RH. For the Fiberite system, it was noticed that the glass transition temperature, $\mathrm{T}_{\mathrm{g}}$, didn't change at the first $1 \%$ absorbed moisture rate. For each $1 \%$ moisture absorbed, $\mathrm{T}_{\mathrm{g}}$, fell by $10{ }^{\circ} \mathrm{C}$ and $15^{\circ} \mathrm{C}$ for Fiberite and Brochier systems, respectively. Further, it was observed that an increase in moisture level was caused to more moisture absorption. The maximum moisture absorption rate in all groups was found between $2.5 \%$ and $6.5 \%$.

At the Wan et al.'s study [5], research was actualized about moisture ingress behavior and its effect on the flexural response of non-hybrid carbon/epoxy, non-hybrid Kevlar/epoxy, and hybrid carbon/Kevlar/epoxy composites. The aging condition was selected as Hanks solution at $37{ }^{\circ} \mathrm{C}$ for $1700 \mathrm{~h}$. It was found that both nonhybrid samples and hybrid samples displayed a Fickian diffusion character. Also, the highest water absorption was observed in the non-hybrid Kevlar/epoxy composite group as $2.18 \%$. Further, the overall water intake rate of non-hybrid Kevlar/epoxy samples was found as bigger than non-hybrid carbon/epoxy and hybrid carbon/Kevlar/epoxy samples.

Yahaya et al. [6] evaluated the aging influence on the impact and physical behaviors of hybrid kenafKevlar composites. Hybrid specimens were kept in distilled water at laboratory conditions for 300 hours. It was observed that as the Kevlar rate increased in hybrid samples, the overall water intake rate decreased. It was noticed that the water absorption rate of non-hybrid Kevlar/epoxy samples was lower than hybrid composites and non-hybrid Kenaf/epoxy composites. The overall water intake rate of non-hybrid Kevlar/epoxy samples was found as $7.83 \%$. 
The hybrid glass/Kevlar specimens were immersed in distilled water at several temperatures and different humidity grades for diverse aging periods at the study of Srivastav et al. [7]. Water absorption behaviors were studied on samples that would be subjected to tensile, flexural, and shear tests. Researchers noticed that the shape of specimens affected the maximum water absorption trend of composites. The maximum water absorption rates were found as $12.38 \%, 4.81 \%$, and $5.487 \%$ for tensile test, flexural test, and shear test samples, respectively.

Imielinska et al. [8] assessed the aging effect on the impact character of two different hybrids aramid-glass fiber/epoxy composites types. Hybrid samples were exposed to distilled water at $70{ }^{\circ} \mathrm{C}$ for 8 weeks. It was noticed that both hybrid types displayed Fickian like water absorption character. Further, it was reported that hybrid type affected the water gain parameters. The maximum water gain ratio and diffusion coefficient of interlayer aramid/glass/epoxy samples were found as bigger than intralayer aramid/glass/epoxy samples. The overall water intake rate of hybrid interlayer and intralayer samples were found as $4.8 \%$ and $4.1 \%$, respectively.

Summaries of some studies on the water absorption behavior of aramid composites, which are few in the literature and generally study different temperature and water types, are given. However, it is substantial to investigate water sorption behavior to predict not only the results that the water absorbed may have but also how water sorption can be reduced. Hence, in this study, dimension effect was studied on the water absorption behavior of aramid/epoxy composites aged in different conditions. Two composite groups with different L/w (length/with) ratios were aged in distilled water and sea water for 6 weeks (1000 hours). The water sorption parameters of aramid/epoxy composites were assessed with criteria such as temperature and water type based on the $\mathrm{L} / \mathrm{w}$ ratio.

\section{MATERIALS AND PROCEDURES}

\subsection{Materials}

In this study, twill woven aramid fabric, with an areal density of $173 \mathrm{~g} / \mathrm{m}^{2}$, was used as a reinforcement phase and an epoxy MGS L 285 resin with MGS H 285 hardener was selected as a matrix system. The mechanical and physical properties of reinforcements and matrix systems are illustrated in Table 1 and Table 2, respectively. The reinforcement materials were supplied from Dost Kimya, Istanbul, Turkey.

Table 1. Mechanical and physical properties of reinforcement

\begin{tabular}{|c|l|l|}
\hline Material & Specifications & Dimensions \\
\hline \multirow{3}{*}{$\begin{array}{c}\text { Aramid } \\
\text { Fabric }\end{array}$} & Areal Density & $173 \mathrm{~g} / \mathrm{m}^{2}$ \\
& Fabric thickness & $0.17 \mathrm{~mm}$ \\
\cline { 2 - 3 } & Tensile Strength & $2750-3000(\mathrm{MPa})$ \\
\cline { 2 - 3 } & Elastic Modulus & $82-124(\mathrm{GPa})$ \\
\hline
\end{tabular}

Table 2. Physical properties of resins systems

\begin{tabular}{|c|l|l|}
\hline Material & Specifications & Dimensions \\
\hline \multirow{2}{*}{ MGS L 285 8 Density } & $1.18-1.23 \mathrm{~g} / \mathrm{cm}^{3}$ \\
& Viscosity & $600-900 \mathrm{mPa} . \mathrm{s}$ \\
\hline \multirow{2}{*}{ MGS H 285 } & Density & $0.94-0.97 \mathrm{~g} / \mathrm{cm}^{3}$ \\
& Viscosity & $50-100 \mathrm{mPa} . \mathrm{s}$ \\
\hline
\end{tabular}

\subsection{Manufacturing Process}

Composite plates were manufactured as twelve ply laminates of twill woven aramid fabric by the vacuum-assisted resin infusion method (VARIM). The resin MGS L 285 and the curing agent the MGS H 285 were prepared with a stoichiometric mass ratio of 100:40. Before the resin/curing agent mixture started to harden, the impregnation process was started. The impregnation process was continued until the aramid fabrics were completely wet. The vacuum pressure control was carried out throughout the process to prevent leakage. The designation of the manufacturing method and production process is showed in Figure $1 \mathrm{a}$ ) and b), respectively. 

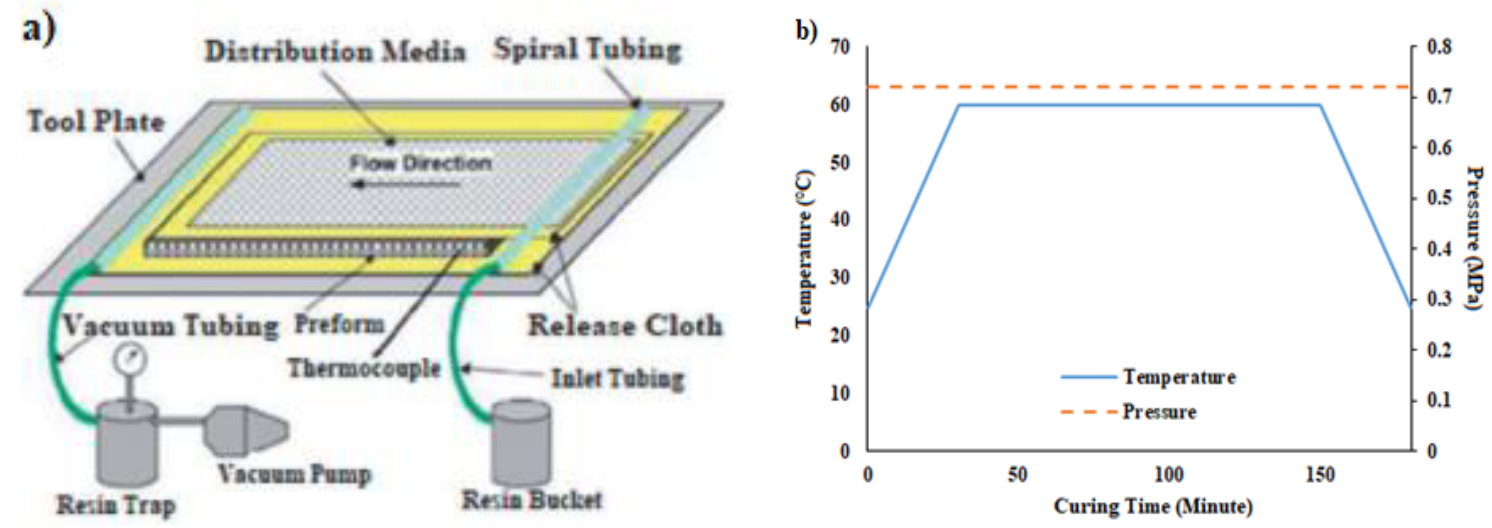

Figure 1. a) Designation of VARIM method [18], b) Production process

Two aramid/epoxy composite groups using different $\mathrm{L} / \mathrm{w}$ ratios were cut from $350 * 500 \mathrm{~mm}^{2}$ plates with a $\mathrm{CNC}$ router. Composite samples with two different widths were cut as L/w ratios were 10 and 15 , by the length remaining constant. The designation of composite sample is illustrated in Figure 2.



Figure 2. Test specimen

\subsection{Hydrothermal Aging}

The composite samples were aged in sea water (SW) and distilled water (DW) at $25^{\circ} \mathrm{C}$ and $70{ }^{\circ} \mathrm{C}$ temperatures for 1000 hours. Because of the geographical position, it is not possible to obtain sea water directly from the sea, artificial sea water was prepared with natural sea salt at a concentration of 3.5 percent, based on the global average concentration of ocean salt. Since this rate shows variation due to evaporation, it was periodically controlled with a suitable densitometer, and fixed with addition of proper amount of water and salt. The aging cabin is illustrated in Figure 3.

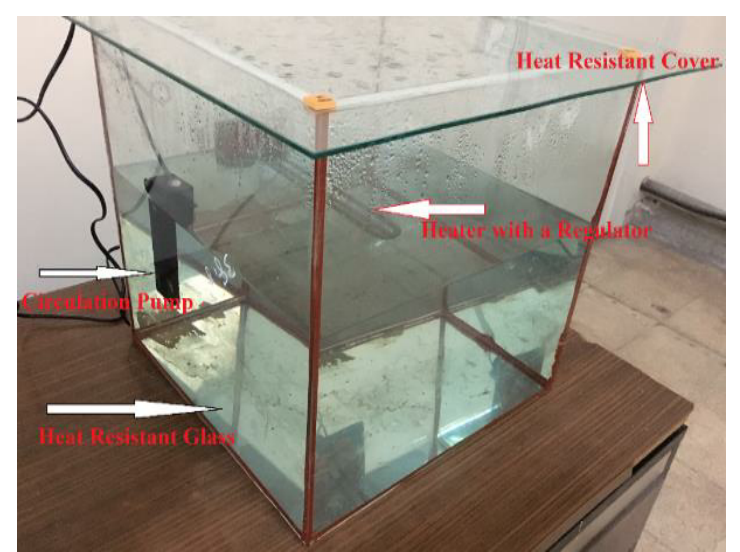

Figure 3. Hydrothermal aging cabin

To prevent restriction of water absorption during the test, the samples that would be immersed in water before the test was not sandpapered due to the sandpapering process could prevent water absorption. Furthermore, to maximize the water absorption, a suitable separator was used to prevent the contact of the samples and to achieve water intake from all surfaces.

Depending on ASTM D5229/D5229M-14 [9], hydrothermal aging was performed in which the water absorption amount $M_{t}$ can be determined as below (Equation 1) 
$M_{t}=\frac{m_{t}-m_{0}}{m_{0}} \times 100$

where $m_{t}$ and $m_{0}$ are the weight at time $t$ and the first weight of specimens, respectively.

Moreover, the water sorption tendency of samples was also computed theoretically based on Fick's law. Fick's law leads with thickness $h$ to the following equation (Equation 2) [10].

$$
\frac{M_{t}}{M_{m}}=1-\frac{8}{\pi^{2}} \sum_{n=0}^{\infty} \frac{1}{(2 n+1)^{2}} \exp \left[\frac{-(2 n+1)^{2} \pi^{2} D t}{h^{2}}\right]
$$

where $M_{t}$ and $M_{m}$ are the water absorption amount $t$ and the overall water gain at equilibrium plateau, respectively and $D$ is the diffusion coefficient.

Shen and Springer [11] simplified the Equation 2 based on $D t / h^{2}$ ratio as (Equation 3-4)

$$
\begin{aligned}
& \frac{M_{t}}{M_{m}}=\left\{\frac{4}{h} \sqrt{\frac{D t}{\pi}} \quad \text { for } \frac{D t}{h^{2}}<0.05\right. \\
& \frac{M_{t}}{M_{m}}=\left\{1-\frac{8}{\pi^{2}} \exp \left[-\frac{\pi^{2} D t}{h^{2}}\right] \quad \text { for } \frac{D t}{h^{2}}>0.05\right.
\end{aligned}
$$

The composite diffusion coefficient $D$ can be calculated as

$$
D=\pi\left(\frac{h}{4 M_{m}}\right)^{2} k^{2}
$$

where $k$ is the initial slope of the plot $M_{t}$ versus square root of time, $\sqrt{t}$.

Due to the water intake experiments involve water intake from all surfaces, the estimated value of $D$ from Equation 5 causes to mistake [12,13]. For the correct diffusion coefficient, a correction factor can be calculated for the edge effect, so the corrected diffusion coefficient $D_{c}$ can be counted as;
$D_{c}=D\left(1+\frac{h}{L}+\frac{h}{w}\right)^{-2}$

where $\mathrm{w}$ and $\mathrm{L}$ are the width and length of the sample, respectively [13].

A nomenclature is given to the samples showing the parameters studied. For instance, 15-DW25 is a specimen that was manufactured with an $\mathrm{L} / \mathrm{w}$ ratio of 15 and aged in distilled water at $25{ }^{\circ} \mathrm{C}$ temperature, whereas 10 -SW70 is a specimen that was manufactured with an $\mathrm{L} / \mathrm{w}$ ratio as 10 and aged in sea water at $70{ }^{\circ} \mathrm{C}$ temperature.

\section{RESULTS AND DISCUSSIONS}

The weight gain rate graphs of aramid/epoxy composites aged at $25{ }^{\circ} \mathrm{C}$ and $70{ }^{\circ} \mathrm{C}$ are shown in Figures 4 and 5, respectively, based on the theoretical $\left(\mathrm{M}_{\mathrm{t}}\right)$ and experimental $\left(\mathrm{M}_{\mathrm{e}}\right)$ measurements. The water gain curves of composites were plotted against the square root of an aging time in figures.

The $M_{t}$, representing Fick's law, and the $M_{e}$, representing the experimental measurements, showed a harmonious appearance in all environments for the two L/w ratios. Hence, it can be said that the water absorption trend of aramid/epoxy composites displayed a trend like the Fickian model.

It was observed that the water absorption behavior of composites was time-dependent. The rapid onset of water absorption started to decrease as the aging period increases. Further, it was noticed that the composite samples approached the almost saturation point at the end of the aging period. The initial rapid water absorption can be caused by the concentration difference between the composite samples and the aging environment. Besides, voids found both at the surface and the fiber/matrix interface can also produce the rapid initial water absorption [14]. 




Figure 4. Water uptake ratio of composites aged at $25{ }^{\circ} \mathrm{C}$

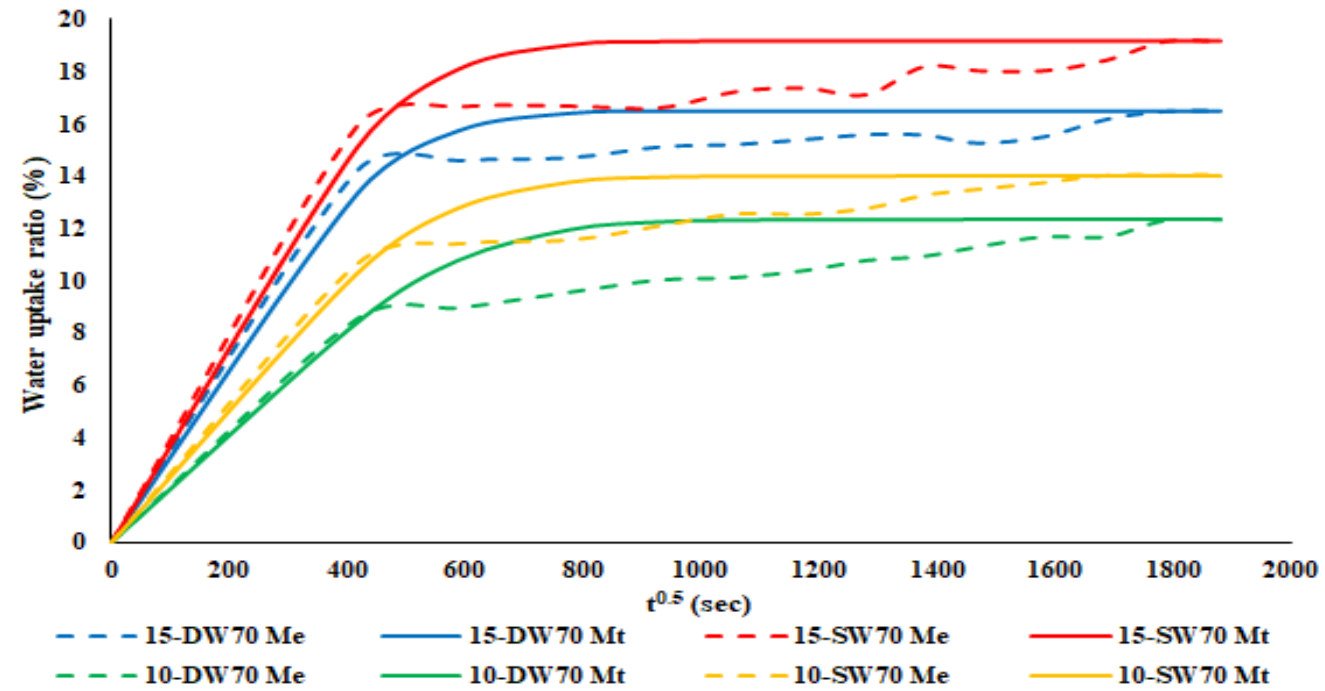

Figure 5. Water uptake ratio of composites aged at $70{ }^{\circ} \mathrm{C}$

The maximum water uptake ratio of aramid/epoxy composites based on the $\mathrm{L} / \mathrm{w}$ ratio is shown in Figure 6. When the maximum water absorption rates of aramid/epoxy composites with different $\mathrm{L} / \mathrm{w}$ ratios were examined based on temperature, it was observed that the temperature directly affected the maximum water absorption rate in both water types. The temperature increase was caused the more water absorption. High temperature is one of the most important factors that disrupt the matrix and fiber/matrix structure. Cracks and voids tend to increase in structures that deteriorate at high temperatures. Voids and cracks filling with water causes excessive water absorption [15]. 




Figure 6. Maximum water uptake ratio of aramid/epoxy composites

Furthermore, the maximum water uptake rate of aramid/epoxy samples was evaluated for different water types and different $\mathrm{L} / \mathrm{w}$ ratios separately. The maximum water absorption rate of aramid/epoxy samples immersed in distilled water was found to be less than samples aged in sea water in both temperatures and $\mathrm{L} / \mathrm{w}$ ratios. Besides, the difference in maximum water ratios was observed more clearly at high temperatures. The more sea water absorption can be explained with the $\mathrm{pH}$ level that causes micro-cracks in the composite structure [16]. Degradation areas in the form of micro-cracks in the composite structure increase the absorption of sea water.

When the water absorption rates were examined based on the sample dimensions, it was noticed that the maximum absorbed water amount of aramid/epoxy composite samples changed under the effect of dimension. Considering the maximum water absorption rate of aramid/epoxy samples aged at the same water type and temperature with different $\mathrm{L} / \mathrm{w}$ ratio, it was observed that the increase of the $\mathrm{L} / \mathrm{w}$ ratio was caused by more water absorption, as seen in Figure 6. The maximum water uptake ratio of samples aged in distilled water at $25^{\circ} \mathrm{C}$ was found as $12.990 \%$ and $11.189 \%$ for 15-DW25 and 10-DW25, respectively. A similar water absorption trend was observed in sea water aging at $25{ }^{\circ} \mathrm{C}$. The maximum water gain ratios were found as $13.010 \%$ and $11.629 \%$ for $15-$ SW25 and $10-$ SW25, respectively. In addition, the effect of the $\mathrm{L} / \mathrm{w}$ ratio on the maximum water intake rate of aramid/epoxy samples aged at $70{ }^{\circ} \mathrm{C}$ was more clearly observed. Compared to specimens immersed at $25{ }^{\circ} \mathrm{C}$, the maximum water uptake rate of specimens immersed at $70{ }^{\circ} \mathrm{C}$ increased more as the $\mathrm{L} / \mathrm{w}$ ratio increased. The maximum water uptake ratio of samples aged in distilled water at $70{ }^{\circ} \mathrm{C}$ was found as $16.470 \%$ and $12.330 \%$ for 15 -DW70 and 10 DW70, respectively. Also, a similar water absorption tendency was observed for the sea water aging process. The maximum water uptake ratio of samples aged in sea water at $70{ }^{\circ} \mathrm{C}$ was found as $19.160 \%$ and $14.041 \%$ for $15-S W 70$ and 10-SW70, respectively.

The diffusion coefficient (D) that displays how much water molecules can penetrate the composite samples is one of the most major factors of Fick's model [17]. The diffusion coefficient (D) and corrected diffusion coefficient $\left(\mathrm{D}_{\mathrm{c}}\right)$ are illustrated in Figure 7. The experimental findings displayed the diffusion coefficient values gave harmonious and uniform results for both temperatures and water types. As seen in Figure 7, the decrease of the $\mathrm{L} / \mathrm{w}$ ratio was caused to fall back of $\mathrm{D}$ values. The diffusion coefficients of composites aged at $25{ }^{\circ} \mathrm{C}$ temperature were found as $8.865 * 10^{-6}$, $8.161 * 10^{-6}, 8.673 * 10^{-6}$, and $7.297 * 10^{-6}$ for 15 DW25, 10-DW25, 15-SW25 and 10-SW25, respectively. Besides, the diffusion coefficients of samples aged at $70{ }^{\circ} \mathrm{C}$ temperature displayed a 
parallel character with $25{ }^{\circ} \mathrm{C}$. The diffusion coefficients of composites aged at $70{ }^{\circ} \mathrm{C}$ temperature were found as $8.079 * 10^{-6}, 5.062 * 10^{-}$
$6,7.514 * 10^{-6}$, and $6.059 * 10^{-6}$ for 15 -DW70, 10 DW70, 15-SW70 and 10-SW70, respectively.

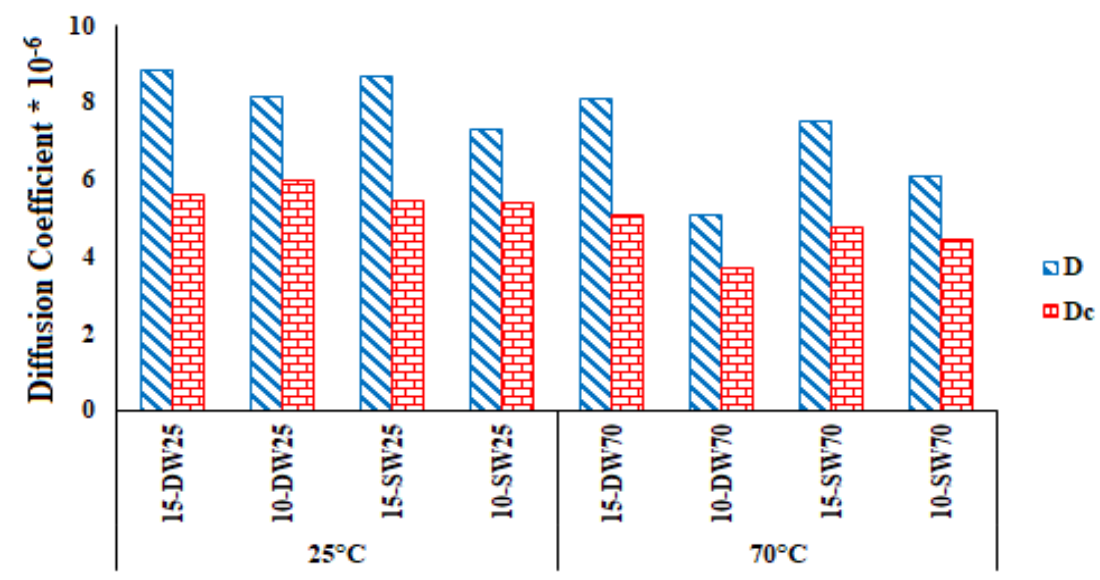

Figure 7. Diffusion coefficients of aramid/epoxy composites

Moreover, as a result of the edge factor, the $D_{c}$ values were found as lower than the $\mathrm{D}$ values. The $\mathrm{D}_{\mathrm{c}}$ values of aramid/epoxy showed a similar trend with $\mathrm{D}$ values, based on the dimension effect. The increase of $\mathrm{L} / \mathrm{w}$ ratio was caused to increase of $\mathrm{D}_{\mathrm{c}}$ values, except from samples aged in distilled water at $25{ }^{\circ} \mathrm{C}$ with a negligible difference, as seen in Figure 7. The corrected diffusion coefficients, $D_{c}$, of composites aged at $25^{\circ} \mathrm{C}$ temperature were found as $5.587 * 10^{-6}, 5.956 * 10^{-6}, 5.467 * 10^{-6}$, and $5.401 * 10^{-6}$ for 15 -DW25, 10-DW25, 15-SW25 and 10-SW25, respectively. Likewise, the corrected diffusion coefficients, $\mathrm{D}_{\mathrm{c}}$, of composites aged at $70{ }^{\circ} \mathrm{C}$ temperature were found as 5.092 $* 10^{-6}, 3.712 * 10^{-6}, 4.736 * 10^{-6}$, and $4.443 * 10^{-6}$ for 15-DW70, 10-DW70, 15-SW70 and 10-SW70, respectively.

\section{CONCLUSION}

In this research, the water sorption character of aramid/epoxy composites was intended to evaluate based on dimension effect. Periodic weight measurements revealed that factors such as water type and temperature directly affected the water sorption character of aramid/epoxy composites. The experimental and theoretical weight measurement lines showed parallel trends. Hence, the water sorption character of aramid/epoxy composites displayed the Fickian model. It was observed that the sea water sorption rate of aramid/epoxy samples was higher than distilled water absorption rate for both temperatures. In addition, it was noticed that the temperature increase was caused by more water absorption for both two L/w ratio and water types. Moreover, when all results were evaluated on the basis of the dimension effect, it was seen that the increase of $\mathrm{L} / \mathrm{w}$ ratio was caused to increase of overall water intake rate, diffusion coefficient and corrected diffusion coefficient.

\section{ACKNOWLEDGEMENT}

This work was supported by the Gaziantep University Scientific Research Project Governing Unit (BAPYB) with an MF.DT.19.08 project number.

\section{REFERENCES}

1. Özbek, Ö., 2021. Axial and Lateral Buckling Analysis of Kevlar/epoxy Fiber-reinforced Composite Laminates Incorporating Silica Nanoparticles, Polymer Composites, 42, 1109-1122. 
2. Özbek, Ö., Doğan, N.F., Bozkurt, Ö.Y., 2020. An Experimental Investigation on Lateral Crushing Response of Glass/carbon Intraply Hybrid Flament Wound Composite Pipes, Journal of the Brazilian Society of Mechanical Sciences and Engineering, 42, 389. doi: 10.1007/s40430-020-02475-3.

3. Tanaka, K., Minoshima, K., Grela, W., Komai, K., 2002. Characterization of the Aramid/ epoxy Interfacial Properties by Means of Pullout Test and Influence of Water Absorption, Composites Science and Technology, 62, 2169-2177.

4. Akay, M., Kong Ah Mud, S., Stanley, A., 1996. Influence of Moisture on the Thermal and Mechanical Properties of Autoclaved and Oven-cured Kevlar-49/epoxy Laminates, Composites Science and Technology, 51, 565-571.

5. Wan, Y.Z., Wang, Y.L., Huang, Y., Luo, H.L., He, F., Chen, G.C., 2006. Moisture Absorption in a Three-dimensional Braided Carbon/Kevlar lepoxy Hybrid Composite for Orthopaedic Usage and its Influence on Mechanical Performance, Composites: Part A: Applied Science and Manufacturing, 37(9), 1480-1484.

6. Yahaya, R., Sapuan, S.M., Jawaid, M., Leman, Z., Zainudin, E.S., 2016. Water Absorption Behaviour and Impact Strength of Kenafkevlar Reinforced Epoxy Hybrid Composites, Advanced Composites Letters, 25(4), 98-102.

7. Srivastav, P.A., Wangikar, K.S., Kale, A.D., 2017. Mechanical Characterization and Effects of Hydrolytic Aging on Glass Kevlar Hybrid Composites, International Journal of Mechanical and Production Engineering, 5(9), 2320-2092.

8. Imielinska, K., Guillaumat, L., 2004. The Effect of Water Immersion Ageing on Lowvelocity Impact Behaviour of Woven Aramidglass Fibre/epoxy Composites, Composites Science and Technology, 64, 2271-2278.

9. ASTM D5229, Standard Test Method for Moisture Absorption Properties and Equilibrium Conditioning of Polymer Matrix Composite Materials.

10. Jost, V.W., 1960. Diffusion in Solids, Liquids, Gases, New York: Academic Press, 652.
11. Shen, C.H., Springer, G.S., 1976. Moisture Absorption and Desorption of Composite Materials, Journal of Composite Material, 10, 2-20.

12. Abd El-baky, M.A., Attia, M.A., 2018. Water Absorption Effect on the In-plane Shear Properties of Jute-glass-carbon-reinforced Composites using Losipescu Test, Journal of Composite Materials.

13. Collings, T.A., Copley, S.M., 1983. On the Accelerated Ageing of CFRP, Composites, 14(3), 180-188.

14. Bian, L., Xiao, J., Zeng, J., Xing, S., 2012. Effects of Seawater Immersion on Water Absorption and Mechanical Properties of GFRP Composites. Journal of Composite Materials, 46(25), 3151-3162. doi: 10.1177/ 0021998312436992.

15. Soykok, I.F., Sayman, O., Pasinli, A., 2013. Effects of Hot Water Aging on Failure Behavior of Mechanically Fastened Glass Fber/Epoxy Composite Joints, Composites Part B, 54, 59-70. doi: 10.1016/j.compositesb.2013. 04.073 .

16. Larbi, S., Bensaada, R., Djebali, S., Bilek, A., 2016. Experimental and Theoretical Study on Hygrothermal Aging Effect on Mechanical Behavior of Fiber Reinforced Plastic Laminates. International Journal of Mechanical, Aerospace, Industrial, Mechatronic and Manufacturing Engineering, 10(7), 1239-1242.

17. Oğuz, Z.A., Erkliğ, A., Bozkurt, Ö.Y., 2020. Degradation of Hybrid Aramid/glass/epoxy Composites Hydrothermally Aged in Distilled Water. Journal of Composite Materials, doi: 10.1177/0021998320984237.

18. Wei, B., Cao, H., Song, S., 2011. Degradation of Basalt Fibre and Glass Fibre/epoxy Resin Composites in Seawater, Corrosion Science, 53(1), 426-431. 
